Information Management and Business Review

Vol. 7, No. 1, pp. 12-22, February 2015 (ISSN 2220-3796)

\title{
Development of Foreign Competitor Identification Index (FCII) in Malaysia
}

\author{
${ }^{1}$ Nur Izzati Ab. Rani*, ${ }^{2}$ Che Maznah Mat Isa, ${ }^{1}$ Christopher Nigel Preece \\ ${ }^{1}$ University Technology of Malaysia, Malaysia \\ ${ }^{2}$ University Technology of MARA, Malaysia \\ *atirani_civil@yahoo.com
}

\begin{abstract}
Most previous studies have dealt with foreign competitors in host country by considering how the contractors compete in international environment. The purpose of this study is to develop a foreign competitor identification index (FCII) by assessing the global orientation of international contractors in Malaysia using various characteristics. The exploratory study is based on the secondary data from Engineering News Record (ENR, 2013) and Construction Industry Development Board (CIDB, 2013) Malaysia. The sampling frame was from the ENR top 250 international contractors operating in more than 100 countries worldwide. Their involvement in international projects includes general building, manufacturing, power, water supply, sewerage/solid waste, industrial process, petroleum, transportation, hazardous waste and telecommunications. Six (6) measurements were used to develop the FCII mode which were based on number of years of experience and number of consecutive years operating in Malaysia, number of countries they are working outside Malaysia, number of projects and number of diversity of projects undertaken in Malaysia, and ranking in ENR. The data was analysed descriptively to make the comparison and establish the findings. Thirty eight (38) out of 250 top international contractors listed by the ENR have been operating in Malaysia. It was observed that that the most competitive contractor with the highest FCII score has more than 12 year of consecutive years working in Malaysia working on 99 projects, operating in more than 20 countries outside Malaysia and ranked at 17th place by the ENR (2013). The study used a sampling frame of population based on ENR. Therefore, the proposed measurements shall be further validated by the subject matter experts. The study will assist local contractors to recognize the foreign competitors in Malaysia and a competitive index model will be further developed to guide the local contractors to prepare themselves to compete with the foreign contractors in Malaysia. Neglecting to properly assess the foreign contractors' characteristics can lead to poor performance in their local business ventures. This study intends to contribute to an improved understanding foreign contractor's competitiveness in relation to the local contractors towards the development of the FCII model. Although there have been various models related to competitive index, there is currently no model that attempts to show the effects of foreign contractors on the local contractors.
\end{abstract}

Keywords: Competitor Index, Competitive Strategy, Foreign Contractors, Local Contractors, Malaysia

\section{Introduction}

The Malaysian construction industry is an important sector in the Malaysian economy beside mining, agricultural, manufacturing and services sector. Construction industry become one of the sector that contribute to the Malaysian economic growth and it related to other sector as it become part of their partner which they are rely on each other (Chia et al., 2014). As shown in Table 1, the percentage share by sector in annual percentage changes in gross domestic product (GDP) from 2006 until 2014. In 2013, the annual percentage changes contribution of the main sector to GDP by agricultural, mining, manufacturing, construction and services is 2.1, 0.5, 3.4, 10.9 and 5.9 percent, respectively. It shows that construction has the highest annual percentage changes of contribution to GDP. In 2014 by forecast which the contribution of agricultural, mining, manufacturing, construction and services sector to GDP are 3.8, 1.6, 3.5, 10.0 and 6.2 annual percentage changes each. Construction industry in Malaysia has strongly growth in the economic although the construction industry output is smaller than other's sector output as studied by Ibrahim et al., (2010). In Figure 1 also show changeability in the annual percentage change growth of construction industry. The construction industry has a higher rate than GDP of growth and it flow parallel to GDP growth. Khan et al. (2014) find out once the economic downturn, it goes as well to construction sector growth will decreasing. 
Government is the main player in guiding local contractors to perform in the Malaysian economic industry. Among government agencies involved in the Malaysian construction industry are Construction Industry Development Board (CIDB), Ministry of Work (KKR), Public Work Department (JKR), Contractor Service Centre (PKK), Board of Engineers Malaysia (BEM), Master Builder Association Malaysia (MBAM) and Board of Architect Malaysia (BAM). All of these government agencies has their own role in guiding the contractors in Malaysia (Kamal et al., 2012).

Table 1: Annual percentage changes sector contribution to GDP

\begin{tabular}{|c|c|c|c|c|c|c|c|c|c|}
\hline \multirow[t]{2}{*}{ Sector } & \multicolumn{9}{|c|}{ Share of GDP (\%) } \\
\hline & 2006 & 2007 & $\begin{array}{c}200 \\
8\end{array}$ & $\begin{array}{c}200 \\
9\end{array}$ & $\begin{array}{c}201 \\
0\end{array}$ & 2011 & $\begin{array}{c}2012 \\
\text { p }\end{array}$ & $\begin{array}{c}2013 \\
p\end{array}$ & $2014^{f}$ \\
\hline Agriculture $^{1}$ & 5.8 & 1.4 & 3.8 & 0.1 & 2.4 & 5.8 & 1.3 & 2.1 & 3.8 \\
\hline Mining & -1.2 & 2.1 & -2.4 & -6.5 & -0.3 & -5.4 & 1.0 & 0.5 & 1.6 \\
\hline Manufacturing & 7.4 & 3.1 & 0.8 & -9.0 & 11.9 & 4.7 & 4.8 & 3.4 & 3.5 \\
\hline Construction & -0.5 & 8.5 & 4.4 & 6.2 & 11.4 & 4.7 & 18.6 & 10.9 & 10.0 \\
\hline Services & 7.2 & 10.0 & 8.6 & 2.9 & 7.4 & 7.1 & 6.4 & 5.9 & 6.2 \\
\hline Add: Import duties & -11.0 & 4.7 & 26.7 & -7.1 & 9.6 & 13.0 & 15.6 & 5.8 & 16.5 \\
\hline GDP & 5.6 & 6.3 & 4.8 & -1.5 & 7.4 & 5.2 & 5.6 & 4.7 & $4.5-5.5$ \\
\hline
\end{tabular}

Economic Planning Unit (EPU) under the Prime Minister Department has outline $10^{\text {th }}$ Malaysian Plan (10MP) which can support and give benefit to the construction industry through the fund facilitation from the government. Government come out with Economic Transformation Program (ETP) to boost economic transformation and achieve higher income status country (Muhamad, Sulaiman, \& Sanusi, 2012). Under ETP there are two plans which are National Key Economic Area (NKEA) and National Key Reformation Area (NKRA). CIDB also launched Construction Industry Master Plan (CIMP) 2006-2015. As reported by Sundaraj (2006), there are 7 strategic thrusts were identified in CIMP which are integrate the construction industry value chain, to enhance productivity and efficiency, strengthen the construction industry's image, strive for the highest standard of quality, occupational safety and health, and environmental practices, develop human resource capabilities and capacities in the construction industry, innovate through research and development and adopt new construction methods, leverage on information and communication technology in the construction industry and benefit from globalization including the export of construction products and services.

Figure 1: Annual change of GDP and construction activities in Malaysia (2006-2014).

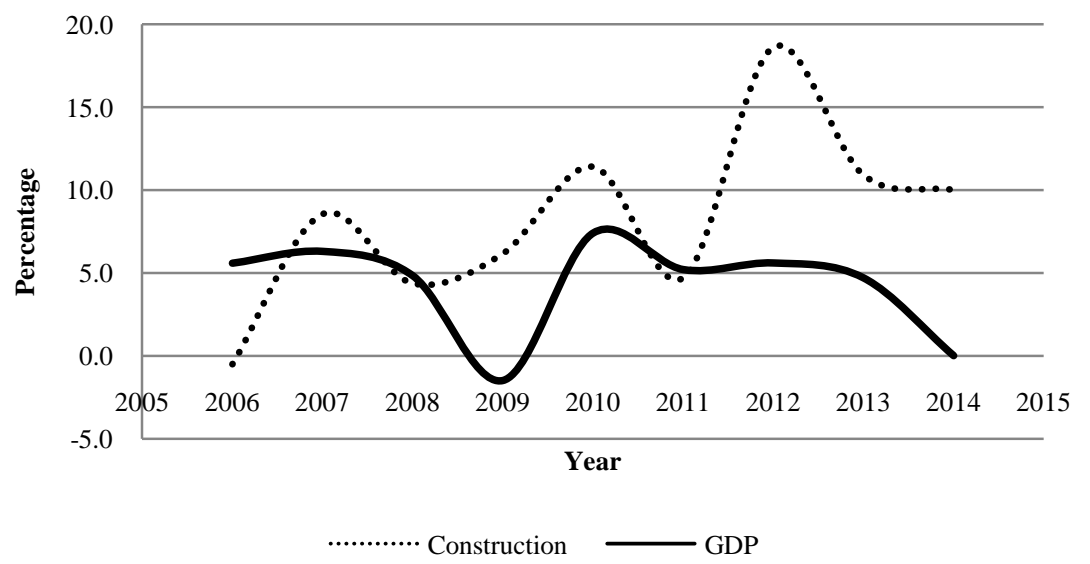

(Source: Department of Statistics, and Central Bank of Malaysia, 2014) 
With all the support from the government agencies, local contractor can get the benefit and perform in the Malaysian construction industry. In Malaysia, registration of the contractors has to go through with two agencies which are CIDB and PKK. In CIDB registration, there are seven registered grade from G1 to G7 and G7 is the largest construction company with paid-up capital RM 750,000 and no limit of tendering capacity. Contractor registered in G6 also under a large construction company with paid-up capital RM 500,000 and tendering capacity not exceeding RM 10 million. Until Jun 2014, there 5,331 contractors registered under G7, while 1,522 contractors registered under G6. These large construction companies have intensity and capacity in bidding projects in the domestic market. In conjunction with the upcoming free trade market, local contractors have to strongest their competitive advantage to compete with the foreign contractors coming in. The aim of this study is to develop the foreign competitor identification index (FCII) in Malaysia. From this index, local contractors can identify who is their competitor in targeted market. The data from Engineering News Record (ENR) report is used as the based because the foreign contractors working in Malaysia and also listed in ENR ranking are the most competence competitors to local contractors.

\section{Literature Review}

The literature that related in this study included competitiveness, years of experience in Malaysia, consecutive year in Malaysia, number of countries, number of projects, diversity of projects and contractor's ranking in ENR.

Competitiveness: Competitiveness can be define as having advantage and capabilities than the competitor and important for the future performance (Orozco et al., 2014). This is important because with the strong capabilities can help the contractor to compete in the future environment challenges as mentioned by Green et al. (2008). Bhala (2014) claimed that upcoming liberalization trade in construction industry such as TransPacific Partnership Agreement (TPPA) will lower the barrier for foreign contractor to enter domestic market and increased foreign direct investment (FDI). So, it is very important for local contractors to intensify their competitive strategies. Local contractors' competitive strategy is determined by the firm's speed relative to competition, specialization, and how it uses its advantages (Chaiprasit \& Swierczek, 2011).

Years of experience in Malaysia: Construction companies that have high or strong experience can be considered to have a competitive advantage. Because from this experience, the contractors can get ready to whatever problem or same problem in finding the solution (Gunhan \& Arditi, 2005). In identify the key competitor of foreign contractor in Malaysia, it is very important to calculate their years of experience in Malaysia. The longer they are working here, the more experience they have in knowing our culture and environment.

Figure 2: International region analysis

Figure 3: International market analysis

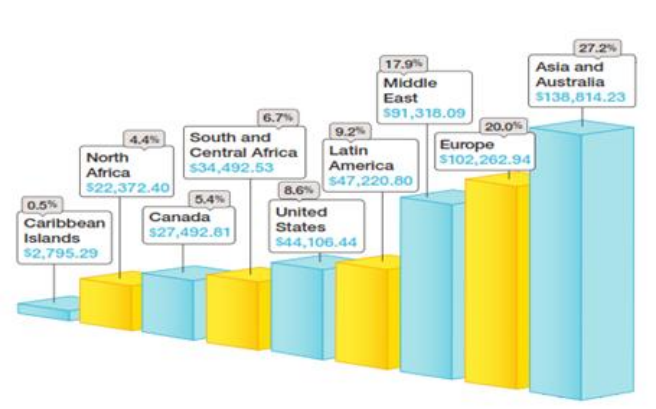

(Source: ENR, 2013)

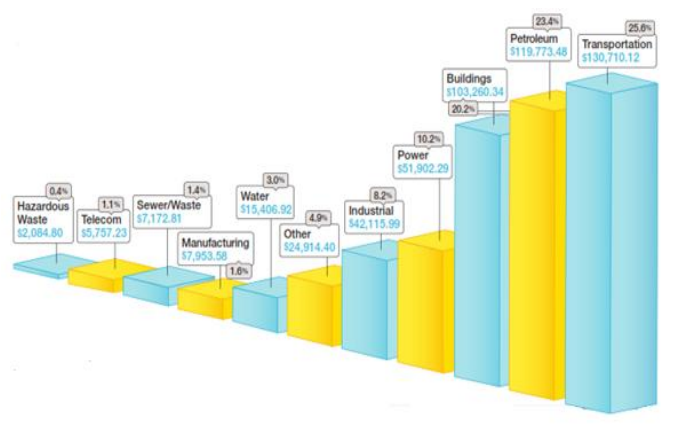

(Source: ENR, 2013)

Consecutive years in Malaysia: Consecutive year is where the foreign contractors keep winning the project and projected to their sustain years in Malaysia. This is because foreign contractors in Malaysia have to register according to their project based. If the years of experience and years of consecutive year of the foreign contractor are long, the foreign contractors are high competitor to local contractors. In one study 
using ENR's list of the top 225 international contractors, only 34 contractors still in four consecutive years from 1998-2001, from 64 contractors in 1998, 74 in 1999, 73 in 2000 and 79 in 2001 (Gunhan \& Arditi, 2005). It shows that not all contractors have strong track record in sustain their business in construction industry.

Number of countries: When the contractor is entering international markets, they will be performing if they can widen their business into other countries or region. The more country they are working, the high competitor they will be to another contractor. In Figure 2, Asian and Australia is the highest value of projects in international regional analysis. It shows that foreign contractors are focusing working in these regions and give high competition to local contractors.

Number of projects: In competing with other contractors, winning a large number of projects can show the construction company can compete with others. In Figure 3, transportation has the highest value of projects, followed by petroleum and building in international market analysis (ENR, 2013).

Diversity of projects: Project diversity is how many types of projects or core business that the company has. For those with same business core or project type will compete strongly according to their competitive advantage (Ye et al., 2014). In Table 2, there is type of projects and their description as stated in ENR.

Table 2: Type of projects and description

\begin{tabular}{|c|c|c|}
\hline No & Type of Project & Description \\
\hline 1 & General Building & $\begin{array}{l}\text { General Building includes commercial buildings, offices, stores, educational } \\
\text { facilities, government buildings, hospitals, medical facilities, hotels, } \\
\text { apartments, housing, etc. }\end{array}$ \\
\hline 2 & Manufacturing & Manufacturing comprises auto, electronic assembly, textile plants, etc. \\
\hline 3 & Power & $\begin{array}{l}\text { Power comprises thermal and hydroelectric power plants, waste-to-energy } \\
\text { plants, transmission lines, substations, cogeneration plants, etc. }\end{array}$ \\
\hline 4 & Water Supply & $\begin{array}{l}\text { Water Supply includes dams, reservoirs, transmission pipelines, distribution } \\
\text { mains, irrigation canals, desalination and drinking-water treatment plants, } \\
\text { pumping stations, etc. }\end{array}$ \\
\hline 5 & Sewerage / Solid Waste & $\begin{array}{l}\text { Sewerage / Solid Waste includes sanitary and storm sewers, treatment } \\
\text { plants, pumping plants, incinerators, industrial waste facilities, etc. }\end{array}$ \\
\hline 6 & Industrial Process & $\begin{array}{l}\text { Industrial Process comprises pulp and paper mills, steel mills, non-ferrous } \\
\text { metal refineries, pharmaceutical plants, chemical plants, food and other } \\
\text { processing plants, etc. }\end{array}$ \\
\hline 7 & Petroleum & $\begin{array}{l}\text { Petroleum includes refineries, petrochemical plants, offshore facilities, } \\
\text { pipelines, etc. }\end{array}$ \\
\hline 8 & Transportation & $\begin{array}{l}\text { Transportation includes airports, bridges, roads, canals, locks, dredging, } \\
\text { marine facilities, piers, railroads, tunnels, etc. }\end{array}$ \\
\hline 9 & Hazardous Waste & $\begin{array}{l}\text { Hazardous Waste includes chemical, nuclear-waste treatment, asbestos and } \\
\text { lead abatement, etc. }\end{array}$ \\
\hline 10 & Telecommunications & $\begin{array}{l}\text { Telecommunications comprises transmission lines, cabling, towers / } \\
\text { antennae, data centres, etc. }\end{array}$ \\
\hline
\end{tabular}

(Source: ENR, 2013)

Contractor's ranking in ENR: In ENR data, the ranking of international contractors is based on their annual revenues outside their home countries as mentioned by Reina \& Tulacz (2012) and Lu (2014). Contractors that have high ranking in ENR are the main competitor to the other contractors, especially for local contractors where the international contractors are working.

\section{Methodology}

In the ENR reports on year 2013 show 66 international companies that are operating in Malaysia but only 38 companies that matched in CIDB records from 1996 until 2013. The year of experience and consecutive years 
in Malaysia will be analysed with data from CIDB while for another four measurements which are the number of countries they are working outside Malaysia, a number of projects, diversity of projects, and contractor's ranking in ENR will be analysed using the ENR data record. Six measurements which are the years of experience in Malaysia, consecutive years in Malaysia, the number of countries they are working outside Malaysia, a number of projects, diversity of projects, and contractor's ranking in ENR listed in Table 3. The contractors are ranked based on the FCII score and their mean value and standard deviation of each dimension also will be calculated. Measurement of FCII is adopted from the secondary data in ENR reports and CIDB also discussion from experts in the construction business. The actual value of years of experience in Malaysia, consecutive years in Malaysia, the number of countries they are working outside Malaysia, a number of projects, diversity of projects, and contractor's ranking in ENR then calculated using the 5 point scale for each dimension as shown in Table 3. The formula of FCII as follows:

$\mathrm{FCKII}=6 \mathrm{~W}_{\mathrm{ym}}+2 \mathrm{~W}_{\mathrm{cm}}+4 \mathrm{~W}_{\mathrm{com}}+3 \mathrm{~W}_{\mathrm{p}}+2 \mathrm{~W}_{\mathrm{d}}+3 \mathrm{~W}_{\mathrm{renr}}$

Where:

FCII = FCII score

$\mathrm{W}_{\mathrm{ym}} \quad=$ weighted measure for years of experience in Malaysia

$\mathrm{W}_{\mathrm{cm}} \quad$ = weighted measure for years sustained consecutive in Malaysia

$\mathrm{W}_{\text {com }} \quad=$ weighted measure for country operated outside Malaysia

$\mathrm{W}_{\mathrm{p}} \quad=$ weighted measure for a number of projects completed in ENR record

$\mathrm{W}_{\text {ed }} \quad=$ weighted measures for a number of diverse projects undertaken

$\mathrm{W}_{\text {renr }} \quad=$ weighted measure for ranking in ENR

Table 3: Scale of each measurement

\begin{tabular}{llllll}
\hline Weightaged & Scale & & & & \\
\cline { 2 - 6 } Measure & $\mathbf{1}$ & $\mathbf{2}$ & $\mathbf{3}$ & $\mathbf{4}$ & $\mathbf{5}$ \\
\hline $\mathrm{W}_{\mathrm{ym}}$ & $<2$ & $2-4$ & $5-7$ & $8-10$ & $>10$ \\
$\mathrm{~W}_{\mathrm{cm}}$ & $<2$ & $2-4$ & $5-7$ & $8-10$ & $>10$ \\
$\mathrm{~W}_{\text {com }}$ & $<20$ & $21-40$ & $41-60$ & $61-80$ & $>80$ \\
$\mathrm{~W}_{\mathrm{p}}$ & $<20$ & $21-40$ & $41-60$ & $61-80$ & $>80$ \\
$\mathrm{~W}_{\mathrm{d}}$ & $<5$ & $5-7$ & $8-10$ & $11-15$ & $>15$ \\
$\mathrm{~W}_{\text {renr }}$ & $201-250$ & $151-200$ & $101-150$ & $51-100$ & $1-50$ \\
\hline
\end{tabular}

There are many types of weighting method of the measurement and one of that is the expert weighting system. However, Du et al., (2014) mentioned that this method is subjective and can lead to different results because different experts have different opinions. In this study, equal weighting cannot be used because the measurement cannot be equal in weight. The six measurements to identify the foreign competitor index in Malaysia have a different measurement scale and importance level.

Table 4: Six measurements with details of foreign competitors in Malaysia

\begin{tabular}{|c|c|c|c|c|c|c|c|}
\hline No & Company & $\begin{array}{l}\text { Year in } \\
\text { M'sia }\end{array}$ & $\begin{array}{l}\text { Consecutive } \\
\text { year in } \\
\text { M'sia }\end{array}$ & $\begin{array}{l}\text { Country } \\
\text { outside } \\
\text { M'sia } \\
\text { (ENR) }\end{array}$ & $\begin{array}{l}\text { No. of } \\
\text { project } \\
\text { (ENR) }\end{array}$ & $\begin{array}{l}\text { Diversity } \\
\text { of } \\
\text { project } \\
\text { (ENR) }\end{array}$ & $\begin{array}{l}\text { Ranking } \\
\text { in ENR }\end{array}$ \\
\hline 1 & Balfour Beatty plc & 12.58 & 12.58 & 22 & 99 & 5 & 17 \\
\hline 2 & Bauer AG & 10.50 & 9.75 & 35 & 97 & 8 & 100 \\
\hline 3 & Bechtel & 2.58 & 2.58 & 28 & 100 & 2 & 3 \\
\hline 4 & $\begin{array}{l}\text { Beijing Construction Eng'g Group Co. } \\
\text { Ltd. }\end{array}$ & 5.08 & 5.00 & 19 & 100 & 4 & 133 \\
\hline 5 & $\begin{array}{l}\text { China National Machinery Industry } \\
\text { Corp. }\end{array}$ & 3.50 & 3.50 & 37 & 99 & 6 & 25 \\
\hline 6 & Chiyoda Corp. & 3.67 & 3.67 & 9 & 97 & 1 & 65 \\
\hline 7 & CTCI Corp. & 2.00 & 2.00 & 9 & 100 & 5 & 109 \\
\hline 8 & Daewoo E\&C Co. Ltd. & 5.00 & 5.00 & 14 & 100 & 4 & 40 \\
\hline 9 & Foster Wheeler AG & 1.50 & 1.50 & 65 & 98 & 2 & 44 \\
\hline 10 & Hyundai Engineering \& Construction & 0.67 & 0.67 & 34 & 99 & 5 & 15 \\
\hline
\end{tabular}




\begin{tabular}{|c|c|c|c|c|c|c|c|}
\hline 11 & $\begin{array}{l}\text { Co. Ltd. } \\
\text { International Co. of Yanjian Group Co. } \\
\text { Ltd. }\end{array}$ & 2.00 & 2.00 & 15 & 100 & 5 & 216 \\
\hline 12 & Ircon International Ltd. & 4.00 & 4.00 & 7 & 98 & 2 & 158 \\
\hline 13 & Jacobs & 1.58 & 1.58 & 45 & 98 & 5 & 55 \\
\hline 14 & JGC Corp. & 3.75 & 3.50 & 13 & 100 & 1 & 32 \\
\hline 15 & Kajima Corp. & 1.50 & 1.50 & 16 & 100 & 6 & 50 \\
\hline 16 & KBR & 3.50 & 3.50 & 41 & 98 & 5 & 29 \\
\hline 17 & Kinden Corp. & 0.58 & 0.58 & 15 & 100 & 8 & 178 \\
\hline 18 & Leighton Holdings Ltd. & 1.17 & 1.17 & 18 & 71 & 6 & 31 \\
\hline 19 & Lend Lease Group & 1.75 & 1.75 & 15 & 100 & 5 & 33 \\
\hline 20 & $\begin{array}{l}\text { Lotte Engineering \& Construction Co. } \\
\text { Ltd. }\end{array}$ & 1.92 & 1.92 & 7 & 100 & 4 & 187 \\
\hline 21 & McConnell Dowell Corp. Ltd. & 0.83 & 0.83 & 12 & 80 & 5 & 105 \\
\hline 22 & Nishimatsu Construction Co. Ltd. & 12.83 & 10.83 & 6 & 85 & 6 & 166 \\
\hline 23 & Obayashi Corp. & 11.67 & 9.08 & 13 & 100 & 6 & 47 \\
\hline 24 & Penta-Ocean Construction Co. Ltd. & 0.67 & 0.67 & 6 & 99 & 6 & 80 \\
\hline 25 & Petrofac Ltd. & 1.08 & 1.08 & 11 & 100 & 1 & 18 \\
\hline 26 & Salini SpA & 3.42 & 3.42 & 31 & 99 & 5 & 27 \\
\hline 27 & Samsung Engineering Co. Ltd. & 7.08 & 1.83 & 19 & 100 & 4 & 13 \\
\hline 28 & Shimizu Corp. & 14.08 & 14.08 & 15 & 99 & 6 & 67 \\
\hline 29 & Sinohydro Group Ltd. & 7.75 & 7.75 & 49 & 97 & 4 & 20 \\
\hline 30 & $\begin{array}{l}\text { Ssangyong Engineering \& Construction } \\
\text { Co. Ltd. }\end{array}$ & 4.83 & 2.25 & 8 & 100 & 3 & 132 \\
\hline 31 & Sumitomo Mitsui Construction Co. Ltd. & 8.33 & 4.42 & 8 & 99 & 5 & 156 \\
\hline 32 & Taikisha Ltd. & 12.17 & 7.00 & 20 & 100 & 2 & 75 \\
\hline 33 & Taisei Corp. & 9.75 & 4.00 & 17 & 72 & 5 & 76 \\
\hline 34 & Takenaka Corp. & 14.58 & 14.58 & 22 & 97 & 3 & 70 \\
\hline 35 & Technip & 2.50 & 2.50 & 60 & 100 & 2 & 11 \\
\hline 36 & Toyo Engineering Corp. & 1.17 & 1.17 & 16 & 100 & 2 & 57 \\
\hline 37 & Toyo-Thai Corp. Public Co. Ltd. & 1.92 & 1.92 & 3 & 38 & 2 & 233 \\
\hline 38 & VINCI & 4.25 & 3.58 & 97 & 91 & 7 & 4 \\
\hline
\end{tabular}

\section{Analysis and Discussion}

Measurement of FCII Score: Measurements of FCII score for each foreign company as shown in Table 5. The example of calculating the FCII scores for Balfour Beatty PLC as below:

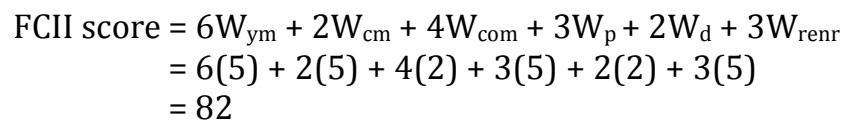

Year of Experience in Malaysia: Years of experience by foreign contractors in Malaysia are calculated starting from their year of establishment in Malaysia by year 2013. In Figure 4, most of foreign contractors working in Malaysia have less than 2 years of experience with 14 contractors, followed by 2 to 4 years of experience with 11 contractors, more than 10 years with 7 contractors, average 5 to 7 years of experience with 4 contractors and from 8 to 10 years of experience with 2 contractors. It shows that many of the contractors still new working in Malaysia but there are also foreign contractors that have long experience in Malaysia. 
Table 5: Measurement of FCKII score

\begin{tabular}{|c|c|c|c|c|c|c|c|c|}
\hline \multirow[t]{2}{*}{ No } & \multirow[t]{2}{*}{ Company } & \multicolumn{6}{|c|}{ Weightage of Measurement } & \multirow{2}{*}{$\begin{array}{c}\text { FKCII } \\
\text { score }\end{array}$} \\
\hline & & Wym & Wem & Wcom & $\mathbf{W p}$ & Wd & Wrenr & \\
\hline 1 & Balfour Beatty plc & 5 & 5 & 2 & 5 & 2 & 5 & 82 \\
\hline 2 & Bauer AG & 5 & 4 & 2 & 5 & 3 & 2 & 73 \\
\hline 3 & Bechtel & 2 & 2 & 2 & 5 & 1 & 5 & 56 \\
\hline 4 & Beijing Construction Eng'g Group Co. Ltd. & 3 & 3 & 1 & 5 & 1 & 3 & 54 \\
\hline 5 & China National Machinery Industry Corp. & 2 & 2 & 2 & 5 & 2 & 5 & 58 \\
\hline 6 & Chiyoda Corp. & 2 & 2 & 1 & 5 & 1 & 2 & 43 \\
\hline 7 & CTCI Corp. & 2 & 2 & 1 & 5 & 2 & 3 & 48 \\
\hline 8 & Daewoo E\&C Co. Ltd. & 3 & 3 & 1 & 5 & 1 & 5 & 60 \\
\hline 9 & Foster Wheeler AG & 1 & 1 & 4 & 5 & 1 & 5 & 56 \\
\hline 10 & Hyundai Engineering \& Construction Co. Ltd. & 1 & 1 & 2 & 5 & 2 & 5 & 50 \\
\hline 11 & International Co. of Yanjian Group Co. Ltd. & 1 & 2 & 1 & 5 & 2 & 1 & 36 \\
\hline 12 & Ircon International Ltd. & 2 & 2 & 1 & 5 & 1 & 2 & 43 \\
\hline 13 & Jacobs & 1 & 1 & 3 & 5 & 2 & 2 & 45 \\
\hline 14 & JGC Corp. & 2 & 2 & 1 & 5 & 1 & 5 & 52 \\
\hline 15 & Kajima Corp. & 1 & 1 & 1 & 5 & 2 & 5 & 46 \\
\hline 16 & KBR & 2 & 2 & 3 & 5 & 2 & 5 & 62 \\
\hline 17 & Kinden Corp. & 1 & 1 & 1 & 5 & 3 & 2 & 39 \\
\hline 18 & Leighton Holdings Ltd. & 1 & 1 & 1 & 4 & 2 & 5 & 43 \\
\hline 19 & Lend Lease Group & 1 & 1 & 1 & 5 & 2 & 5 & 46 \\
\hline 20 & Lotte Engineering \& Construction Co. Ltd. & 1 & 1 & 1 & 5 & 1 & 2 & 35 \\
\hline 21 & McConnell Dowell Corp. Ltd. & 1 & 1 & 1 & 4 & 2 & 3 & 37 \\
\hline 22 & Nishimatsu Construction Co. Ltd. & 5 & 5 & 1 & 5 & 2 & 2 & 69 \\
\hline 23 & Obayashi Corp. & 5 & 4 & 1 & 5 & 2 & 5 & 76 \\
\hline 24 & Penta-Ocean Construction Co. Ltd. & 1 & 1 & 1 & 5 & 2 & 4 & 43 \\
\hline 25 & Petrofac Ltd. & 1 & 1 & 1 & 5 & 1 & 5 & 44 \\
\hline 26 & Salini SpA & 2 & 2 & 2 & 5 & 2 & 5 & 58 \\
\hline 27 & Samsung Engineering Co. Ltd. & 3 & 1 & 1 & 5 & 1 & 5 & 56 \\
\hline 28 & Shimizu Corp. & 5 & 5 & 1 & 5 & 2 & 4 & 75 \\
\hline 29 & Sinohydro Group Ltd. & 3 & 3 & 3 & 5 & 1 & 5 & 68 \\
\hline 30 & Ssangyong Engineering \& Construction Co. Ltd. & 2 & 2 & 1 & 5 & 1 & 3 & 46 \\
\hline 31 & Sumitomo Mitsui Construction Co. Ltd. & 4 & 2 & 1 & 5 & 2 & 2 & 57 \\
\hline 32 & Taikisha Ltd. & 5 & 3 & 1 & 5 & 1 & 4 & 69 \\
\hline 33 & Taisei Corp. & 4 & 2 & 1 & 4 & 2 & 4 & 60 \\
\hline 34 & Takenaka Corp. & 5 & 5 & 2 & 5 & 1 & 4 & 77 \\
\hline 35 & Technip & 2 & 2 & 3 & 5 & 1 & 5 & 60 \\
\hline 36 & Toyo Engineering Corp. & 1 & 1 & 1 & 5 & 1 & 4 & 41 \\
\hline 37 & Toyo-Thai Corp. Public Co. Ltd. & 1 & 1 & 1 & 2 & 1 & 1 & 23 \\
\hline 38 & VINCI & 2 & 2 & 5 & 5 & 2 & 5 & 70 \\
\hline \multicolumn{2}{|c|}{ Mean } & 2.39 & 2.16 & 1.58 & 4.84 & 1.61 & 3.79 & Average \\
\hline \multicolumn{2}{|c|}{ Weighted Mean } & 14.34 & 4.32 & 6.32 & 14.52 & 3.22 & 11.37 & 54.11 \\
\hline \multicolumn{2}{|c|}{ Standard Deviation } & 1.50 & 1.29 & 0.98 & 0.55 & 0.59 & 1.38 & \\
\hline
\end{tabular}

Figure 4: Years of experience foreign contractors in Malaysia

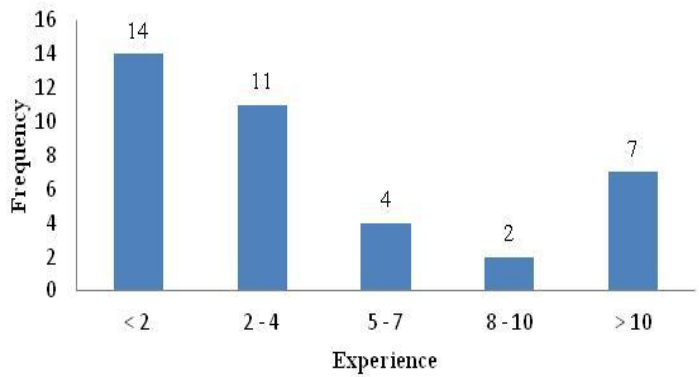

Figure 5: Years of consecutive year by foreign contractors in Malaysia

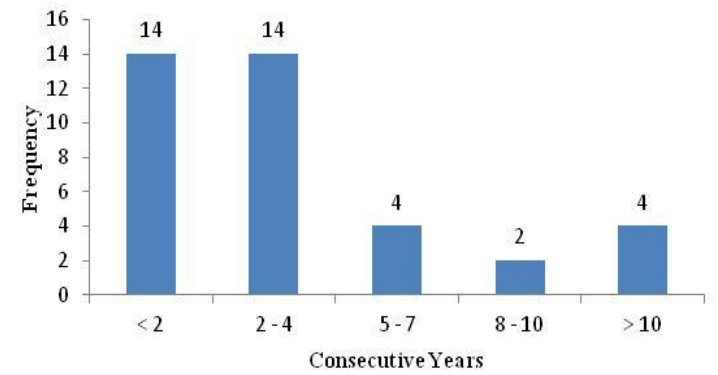

Consecutive Years: Consecutive years of the company depend on their continuing in gathering the projects. In Malaysia, foreign contractors are registered by projects. Once they have completed the project, they have to go back to their home country. From Figure 5, most of foreign contractors have consecutive years less than 
2 years and also 2 to 4 years with 14 companies each. Then 4 companies have 5 to 7 consecutive years and more than 10 years while 2 companies have 8 to 10 consecutive years. Not so many foreign contractors that can continue getting projects in Malaysia because of the term and regulation for foreign company registration or by project based.

Country outside Malaysia: In ENR data, the operating country of each international contractor can be list down by looking at where they worked with country. In Figure 6, the most preferred working country of foreign contractors is Asia/Australia with 297 projects, the second highest is Europe with 182 projects and third highest is Middle East with 136 projects. Other country are Central and Southern Africa with 96 projects, Latin America with 64 projects, North Africa with 62 projects, North America with 39 projects, Caribbean Islands with 11 projects and Antarctic/Arctic with one project.

Figure 6: Working countries of foreign contractors outside Malaysia with projects in ENR

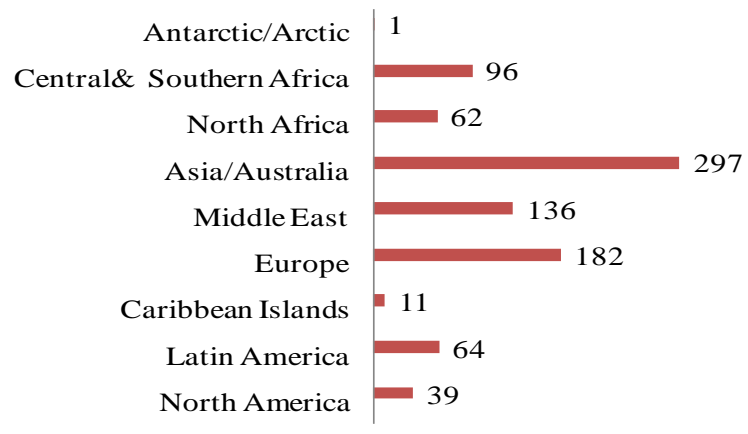

(Source: ENR, 2013)

Foreign companies that venture in the Malaysian construction market also working in other Asian country. These show local contractors have to strong their competitive advantage to compete with these foreign contractors. In the future, they will focus working in Asian countries for example, in Malaysia because in developing countries, development of the countries is demanding. The need to build infrastructure and basic facilities such as houses, schools, roads and hospitals will demand the construction works and more opportunity to contractors (Majid et al., 2004).

Number of projects with type of projects: In Figure 7, industrial process/ petroleum have the highest number of projects with 1329 projects, followed by general building with 772 projects and transportation with 690 projects. Another type of projects such as power with 412 projects, manufacturing with 270 projects, water supply with 115 projects, telecommunications with 71 projects, sewer/ solid waste with 50 projects and hazardous waste with one project.

Figure 7: Number of projects by foreign contractors in Malaysia (1996-2013)

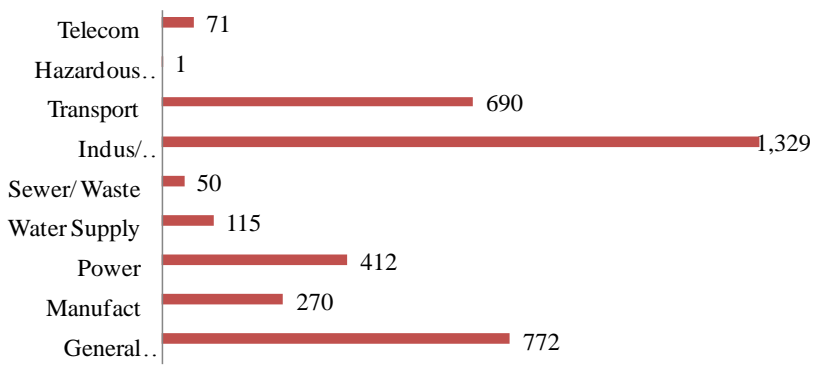

(Source: ENR, 2013)
Figure 8: Number of projects by foreign contractors in ENR

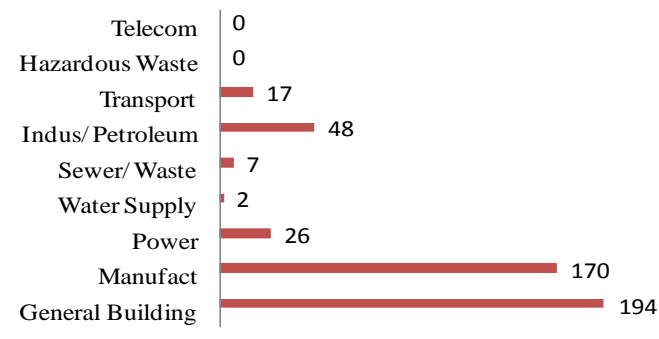

(Source: CIDB, 2013) 
In Figure 8, the highest number of projects by foreign contractors is general building with 194 projects, manufacturing with 170 projects, industrial process/ petroleum with 48 projects, power with 26 projects, transportation with 17 projects, sewer/ solid waste with 7 projects and water supply with 2 projects. However, none of foreign companies have projects in telecommunication and hazardous waste. Local contractors that have a core business in industrial process/ petroleum, transportation and power have to strongest their expertise to compete with foreign contractors because they might have projects in those types of work based on their achievement bidding projects in international market as in Figure 7.

Diversity of projects: The highest number of diversity of projects by foreign contractors is 5 diversity by 11 contractors, followed by 2 and 6 diversity by seven contractors each, 4 diversity by five contractors, 1 and 3 diversity by three contractors each, 8 diversity by two contractors, 7 diversity by one contractor and none of foreign contractors have 9 diversity of projects as shown in Figure 9.

Figure 9: Number of diversity of projects by foreign contractors in ENR

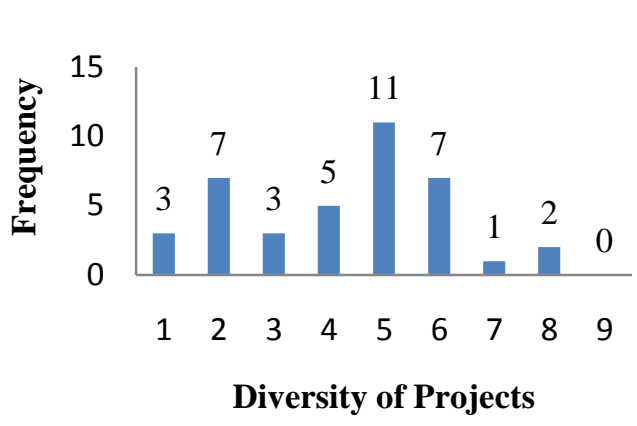

(Source: ENR, 2013)

\section{Figure 10: Number of diversity of projects by foreign contractors in Malaysia (1996-2013)}

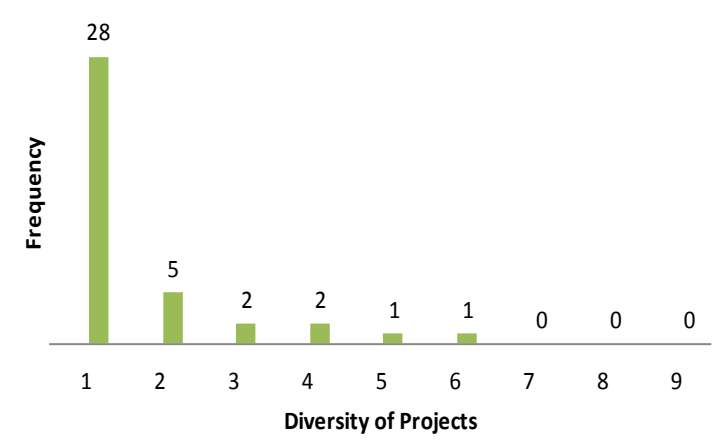

(Source: CIDB, 2013)

It is different with the diversity of projects by foreign contractors in Malaysia as shown in Figure 10 above with the highest number is one diversity by 28 contractors, followed by 2 diversity by five contractors, 3 and 4 diversity by two contractors each, 5 and 6 diversity by one contractor each. None of the contractors have 7 , 8 or 9 diversity of projects in Malaysia. In future, they might increase their diversity of projects in Malaysia and local contractor may be able to merge with other local contractors to increase their diversity of projects or add their core business. High competition in same diversity of projects will push contractor to discover other potential market (Ye et al., 2014). This decision can help local contractors to compete with the foreign contractors.

Contractors ranking: In Table 6, the company is listed according to their ranking and also stated their origin country. The top company in the ranking is the Balfour Beatty PLC, which in ENR 2013, the core business of the company is general building, 48 projects, transport 32 projects, telecommunications 12 projects, power 4 projects and sewer/waste is 3 projects. But in Malaysia, the company only works in transportation with 5 mega projects in Malaysia. It can give high competition with the local that has core business in transportation. Balfour Beatty PLC also might have another type of projects in Malaysia in the future.

\section{Conclusion and Recommendations}

This study will help local contractors to know who their foreign competitors in the Malaysian construction industry are. Although in Malaysia the foreign company just working in one or two types of works than their core of business, they might grab the chance in the future to have more diversity of projects. Local contractors must strengthen their competitive advantage and know their competitors' diversity of projects so that they can have the chance to bid more projects in the domestic market. With the upcoming liberalization and globalization, the local contractors will be more prepared and can be secure in their own country. In the future research, foreign contractors who are working with other Asian countries, in Far East countries and 
also outside the Far East also should be identified. This is because those contractors might work in Malaysia in the future when the Malaysian government sign up that free trade market agreement.

Table 6: Foreign contractors ranking in FCKII

\begin{tabular}{|c|c|c|}
\hline Ranking & Company & Origin \\
\hline 1 & Balfour Beatty plc & London, U.K. \\
\hline 2 & Obayashi Corp. & Tokyo, Japan \\
\hline 3 & Takenaka Corp. & Osaka, Japan \\
\hline 4 & Shimizu Corp. & Tokyo, Japan \\
\hline 5 & Bauer AG & Schrobenhausen, Germany \\
\hline 6 & VINCI & Rueil-Malmaison, France \\
\hline 7 & Sinohydro Group Ltd. & Beijing, China \\
\hline 8 & Taikisha Ltd. & Tokyo, Japan \\
\hline 9 & Nishimatsu Construction Co. Ltd. & Tokyo, Japan \\
\hline 10 & KBR & Houston, Texas, U.S.A \\
\hline 11 & Daewoo E\&C Co. Ltd. & Seoul, S. Korea \\
\hline 12 & Technip & Paris, France \\
\hline 13 & China National Machinery Industry Corp. & Beijing, China \\
\hline 14 & Salini SpA & Rome, Italy \\
\hline 15 & Bechtel & San Francisco, Calif., U.S.A \\
\hline 16 & Foster Wheeler AG & Hampton, N.J., U.S.A. \\
\hline 17 & Samsung Engineering Co. Ltd. & Seoul, S. Korea \\
\hline 18 & Sumitomo Mitsui Construction Co. Ltd. & Tokyo, Japan \\
\hline 19 & Taisei Corp. & Tokyo, Japan \\
\hline 20 & Beijing Construction Eng'g Group Co. Ltd. & Beijing, China \\
\hline 21 & JGC Corp. & Yokohama, Japan \\
\hline 22 & Hyundai Engineering \& Construction Co. Ltd. & Seoul, S. Korea \\
\hline 23 & CTCI Corp. & Taipei, Taiwan \\
\hline 24 & Lend Lease Group & Millers Point, New South Wales, Australia \\
\hline 25 & Kajima Corp. & Tokyo, Japan \\
\hline 26 & Ssangyong Engineering \& Construction Co. Ltd. & Seoul, S. Korea \\
\hline 27 & Petrofac Ltd. & Jersey, Channel Islands, U.K. \\
\hline 28 & Penta-Ocean Construction Co. Ltd. & Tokyo, Japan \\
\hline 29 & Jacobs & Pasadena, Calif., U.S.A. \\
\hline 30 & Ircon International Ltd. & New Delhi, Delhi, India \\
\hline 31 & Chiyoda Corp. & Yokohama, Kanagawa Pref., Japan \\
\hline 32 & Toyo Engineering Corp. & Chiba, Japan \\
\hline 33 & Leighton Holdings Ltd. & St. Leonards, New South Wales, Australia \\
\hline 34 & Kinden Corp. & Tokyo, Japan \\
\hline 35 & International Co. of Yanjian Group Co. Ltd. & Yantai City, China \\
\hline 36 & Lotte Engineering \& Construction Co. Ltd. & Seoul, S. Korea \\
\hline 37 & McConnell Dowell Corp. Ltd. & Hawthorn, Victoria, Australia \\
\hline 38 & Toyo-Thai Corp. Public Co. Ltd. & Bangkok, Thailand \\
\hline
\end{tabular}

\section{References}

Bhala, R. (2014). Trans-Pacific Partnership or Trampling Poor Partners?A Tentative Critical Review. International Economic Law, 11(1).

Chaiprasit, S. \& Swierczek, F. W. (2011). Competitiveness, Globalization And Technology Development In Thai Firms. Competitiveness Review: An International Business Journal Incorporating Journal of Global Competitiveness, 21(2), 188-204.

Chia, F. C., Skitmore, M., Runeson, G. \& Bridge, A. (2014). Economic development and construction productivity in Malaysia. Construction Management and Economics, 32(9), 874-887. 
Du, Q., Wang, Y., Ren, F., Zhao, Z., Liu, H., Wu, C. \& Shen, Y. (2014). Measuring and Analysis of Urban Competitiveness of Chinese Provincial Capitals in 2010 under the Constraints of Major FunctionOriented Zoning Utilizing Spatial Analysis. Sustainability, 6(6), 3374-3399.

Green, S. D., Larsen, G. D. \& Kao, C. (2008). Competitive Strategy Revisited: Contested Concepts And Dynamic Capabilities. Construction Management and Economics, 26(1), 63-78.

Gunhan, S. \& Arditi, D. (2005). Factors Affecting International Construction. Journal of Construction Engineering and Management, 131, 273-282.

Ibrahim, A. R., Bin-Roy, M. H., Ahmed, Z. \& Imtiaz, G. (2010). An Investigation Of The Status Of The Malaysian Construction Industry. Benchmarking: An International Journal, 17(2), 294-308.

Kamal, E. M., Haron, S. H., Ulang, N. \& Baharum, F. (2012). The Critical Review on the Malaysian Construction Industry. Journal of Economics and Sustainable Development, 3(13), 81-87.

Khan, R. A., Liew, M. S. \& Ghazali, Z. (2014). Malaysian Construction Sector and Malaysia Vision 2020 : Developed Nation Status. Procedia - Social and Behavioral Sciences, 109, 507-513.

Lu, W. (2014). Reliability of Engineering News-Record International Construction Data. Construction Management and Economics, (June), 1-15.

Majid, S., Bakar, R. A., Sieh, L., Sieh, P. \& Mei, L. (2004). Impact of AFTA on ACF member countries. The ASEAN Construction Federation (ACF), 36-87.

Muhamad, S., Sulaiman, N. F. C. \& Sanusi, N. A. (2012). Innovative Capacity, Human Capital and Its Contribution to Economic Development in Malaysia. World Journal of Social Sciences, 2(6), 218-230.

Orozco, F. A., Serpell, A. F., Molenaar, K. R., Asce, M. \& Forcael, E. (2014). Modeling Competitiveness Factors and Indexes for Construction Companies : Findings of Chile. Journal of Construction Engineering and Management, 140, 1-13.

Reina, P. \& Tulacz, G. J. (2012). The Top 250 International Contractors (pp. 1-19).

Sundaraj, G. (2006). The Way Forward : Construction Industry Master Plan 2006-2015. The Engenieur Sept, 6, $48-51$.

Ye, K., Shen, L. \& Lu, W. (2014). Discriminant Model For Measuring Competition Intensity Of Construction Market. Engineering, Construction and Architectural Management, 21(2), 152-169. 